大阪市中央急病診療所における異物患者の現沉

$\begin{array}{crrr}\text { *長谷川 } & \text { 哲, } & \text { 渡部 } & \text { 泰夫 } \\ \text { **石田 } & \text { 稔, } & * * * \text { 玉置 } & \text { 弘光 } \\ \text { ****松永 } & \text { 亨, } & * * * * * \text { 蛭沼 } & \text { 進 } \\ \text { 植松 } & \text { 治雄, } & \text { 楠岡 } & \text { 一雄 }\end{array}$

\title{
Foreign Bodies in Nose, Throat and Esophagus Handled in an Emergency Clinic during Last 6 Years
}

\author{
Satoshi Hasegawa, M.D. and Yasuo Watanabe, M.D.
}

Department of Otorhinolaryngology, Osaka Prefectural Hospital, Osaka

Minoru Ishida, M.D.

Department of Otorhinolaryngology, Suita Municipal Hospital, Osaka

Hiromitsu Tamaki, M.D.

Department of Otorhinolaryngology, Kagawa Medical College, Kagawa

\section{Toru Matsunaga, M.D.}

Department of Otorhinolaryngology, Osaka University School of Medicine, Osaka

\author{
Susumu Hirunuma, M.D., Haruo Uematsu, M.D. \\ and Kazuo Kusuoka, M.D. \\ Osaka Medical Association, Osaka
}

A statistical study was conducted on the cases of foreign bodies handled in an emergency ENT clinic during the period from 1978 through 1983.

The results were as follows;

1. During the 6 year period, 473 patients $(2.1 \%)$ out of a total of 22408 patients presented with foreign bodies.

2. The locations of the foreign bodies were; 219 cases in the nose, 206 in the pharynx, 28 in the larynx, 1 in the trachea and 19 in the esophagus.

3. More than $50 \%$ of the 473 cases were infants. Of the cases having foreign bodies in the nose, $90 \%$ were infants.

4. One hundred and nineteen (54.4\%) of the 219 foreign bodies found in the nose were spheroidal. Two hundred and sixteen (92.3\%) of the 234 foreign bodies found in the larynx and pharynx were fish bones. Thirteen (68.4\%) of the 19 foreign bodies found in the esophagus were coins, and in 9 of the 13 cases coins were lodged at the entrance of the esophagus. The foreign bodies found in the trachea of one case were beans.

5. Two hundred and seventy seven $(58.6 \%)$ of the 473 cases were treated within 6 hours.

Key words : 異物症, 頻度, 部位, 年齥

\footnotetext{
*大阪府立病院耳鼻咽喉科

***香川医科大学耳鼻咽喉科 $* * * * *$ 大阪医会
}

\section{**市立吹田市民病院耳鼻咽喉科 ****大阪大学医学部耳鼻咽喉科}




\section{I 緒 言}

われわれは，昭和53年12月より， 昭和58年 6 月までに，大阪市中央急 病診療所を受診した異物症例の, 統 計的観察を試みたので報告する。

\section{II 異物症の統計}

表 1 は年度別の部位別異物症例数 である。 53 年度は，53年 12 月より 54 年 3 月までの 4 力月間, 58 年度は, 58 年 4 月より 6 月末での 3 力月間の 統計をとっているため，受診総症例 数, 異物症例数ともに少なくなって いる。この期間に，鼻・咽喉頭，食 道・胃腸，気管の異物症，またはそ の疑いで受診したものは797症例で， そのらち，異物を確認できたものは 473 症例で あった。以下，この473症例について報告する。

年度により, 表 1 飞示すように多少の変動は あるが，全症例に対する異物症の割合は，平均 $2.1 \%$ となっている。また，表 1 には示してい ないが，この期間に耳内異物確認症例が各年度 ごとに，12例，48例，46例，50例，44例，20例 の計 220 例あり，それらを含めると異物症例は 693例となり，総症例数に対する割合は，3.1\% となる。

また，部位別にみると，耳内異物が 220 例， 鼻腔内異物が 219 例, 咽頭異物が 206 例で, 各 各約 $30 \%$ を占め, 喉頭異物が 28 例で $4 \%$, 食道 ・胃腸異物は 19 例で $3 \%$ ，注かに気管異物が 1 例であった。

この割合を他の報告例と比較してみる。昭和 31 年より昭和 40 年までの大阪大学耳鼻咽喉科に 扣ける報告 ${ }^{1)}$ では，食道胃腸異物 $66 \%$ ，咽頭異 物 $17 \%$ ，気管喉頭異物 $6 \%$ ，耳内異物 $8 \%$ ，鼻 腔内異物 $4 \%$ となって招り，かなりの違いが認 められる。また，西浦による昭和 44 年より 55 年 までの報告2)では，耳内異物 $45 \%$ ，鼻腔内異物 $14 \%$, 口腔咽頭異物 $35 \%$, 食道異物 $4 \%$, 喉頭 気管異物 $4 \%$ と，われわれとかなり似た数值が 報告されて扣り，異物症の統計に関して，総合 病院と開業医あるいは診療所とに搞ける，症例 の種類に違いのあることが確認できた。

表 2 は, 異物症例全体の年齢との関 係を示
表 1 年度, 部位別異物症例数

\begin{tabular}{|c|c|c|c|c|c|c|}
\hline \begin{tabular}{l|l} 
晾異 & 物 \\
例
\end{tabular} & 鼻 & 咽頭 & 喉頭 & 気管 & 食道 & $\%$ \\
\hline 53 & 19 & 22 & 3 & 0 & 9 & \\
\hline 35 & 19 & 15 & 1 & 0 & 0 & 2.1 \\
\hline 175 & 50 & 70 & 15 & 5 & 35 & \\
\hline 94 & 45 & 39 & 5 & 1 & 4 & 2. \\
\hline 180 & 59 & 76 & 15 & 3 & 27 & \\
\hline 106 & 53 & 45 & 5 & 0 & 3 & 2.1 \\
\hline 160 & 45 & 72 & 13 & 5 & 25 & \\
\hline 93 & 37 & 45 & 8 & 0 & 3 & 1.8 \\
\hline 185 & 56 & 82 & 19 & 1 & 27 & \\
\hline 121 & 54 & 54 & 7 & 0 & 6 & 2.3 \\
\hline 44 & 12 & 16 & 3 & 0 & 13 & \\
\hline 24 & 11 & 8 & 2 & 0 & 3 & 2.3 \\
\hline 473 & 219 & 206 & 28 & 1 & 19 & 2.1 \\
\hline
\end{tabular}

表 2 年秢・性別の異物症例数

\begin{tabular}{c|rr|r|r}
\hline 年 齢 & 男性 & 女性 & \multicolumn{1}{|c|}{ 計 } & $\%$ \\
\hline $0 \sim 5$ & 141 & 109 & 250 & 53.1 \\
$6 \sim 10$ & 28 & 12 & 40 & 8.4 \\
$11 \sim 20$ & 9 & 10 & 19 & 4.0 \\
$21 \sim 30$ & 20 & 15 & 35 & 7.4 \\
$31 \sim 40$ & 21 & 17 & 38 & 8.1 \\
$41 \sim 50$ & 16 & 12 & 28 & 5.9 \\
$51 \sim 60$ & 7 & 19 & 26 & 5.5 \\
$61 \sim$ & 14 & 22 & 36 & 7.6 \\
\hline 計 & 256 & 216 & 472 & 100 \\
\hline
\end{tabular}

（年齢不明 1 症）

表 3 鼻腔内異物症例年齢分布

\begin{tabular}{c|rr|r|r}
\hline 年 齢 & \multicolumn{1}{|c|}{ 男 } & 女 & 計 & \multicolumn{1}{c}{$\%$} \\
\hline $0 \sim 5$ & 117 & 88 & 205 & 93.6 \\
$6 \sim 10$ & 10 & 3 & 13 & 5.9 \\
$11 \sim 60$ & 0 & 0 & 0 & 0 \\
$61 \sim$ & 1 & 0 & 1 & 0.5 \\
\hline 計 & 128 & 91 & 219 & 100 \\
\hline
\end{tabular}

す。 0 〜 歳までが 250 例で $53.1 \%$ と約半数を 占める。11〜20歳が最も少ない。性別では, 50 歳以下はやや男性が多いようであるが，50歳以 上では, 逆に女性に多くなっている。部位別に みると, 鼻腔内異物（表 3 ）では，5歳以下が 圧倒的に多〈93.6\%を占め，11歳以上の症例 は，わずか 1 例だけであった。咽頭異物(表 4) 
表 4 咽喉頭異物症例の年齢分布

\begin{tabular}{c|rr|r|r|rr|r|r}
\hline \multirow{2}{*}{ 年 齢 } & \multicolumn{2}{|c|}{ 咽 } & \multicolumn{2}{|c|}{ 頭 } & \multicolumn{2}{|c|}{ 喉 } & \multicolumn{2}{|c}{ 頭 } \\
\cline { 2 - 8 } & 男 & 女 & 計 & $\%$ & 男 & 女 & 計 & $\%$ \\
\hline $0 \sim 5$ & 18 & 13 & 31 & 15.0 & 0 & 0 & 0 & 0 \\
$6 \sim 10$ & 16 & 8 & 24 & 11.7 & 0 & 0 & 0 & 0 \\
$11 \sim 20$ & 7 & 10 & 17 & 8.3 & 2 & 0 & 2 & 7.4 \\
$21 \sim 30$ & 19 & 14 & 33 & 16.0 & 1 & 1 & 2 & 7.4 \\
$31 \sim 40$ & 19 & 15 & 34 & 16.5 & 2 & 2 & 4 & 14.8 \\
$41 \sim 50$ & 14 & 12 & 26 & 12.6 & 2 & 0 & 2 & 7.4 \\
$51 \sim 60$ & 6 & 16 & 22 & 10.7 & 1 & 2 & 3 & 11.1 \\
$61 \sim$ & 9 & 10 & 19 & 9.2 & 4 & 10 & 14 & 51.9 \\
\hline 計 & 108 & 98 & 206 & 100 & 12 & 15 & 27 & 100 \\
\hline
\end{tabular}

表 6 年度別鼻腔内異物別頻度

\begin{tabular}{|c|c|c|c|c|c|c|c|c|c|c|c|c|}
\hline & $\begin{array}{l}\text { 球 } \\
\text { 形 } \\
\text { 物 }\end{array}$ & $\begin{array}{l}\text { プ } \\
\text { ラ } \\
\text { ス } \\
\text { チ } \\
\text { y } \\
ク \\
\text { 片 }\end{array}$ & 豆 & 玩 & 種 & 紙 & ボ & 綿 & $\begin{array}{l}ク \\
レ \\
\exists \\
ン\end{array}$ & $\begin{array}{l}\text { ケ } \\
\text { シ } \\
\text { ב゙ } \\
ム\end{array}$ & 他 & 計 \\
\hline S 53 & & & & & & & & 1 & & & & 1 \\
\hline S 54 & 14 & 6 & 3 & 3 & 3 & 1 & 4 & 2 & 3 & 1 & 15 & 55 \\
\hline S 55 & 11 & 9 & 2 & 4 & 7 & & 1 & 2 & & & 14 & 50 \\
\hline S 56 & 11 & 5 & 3 & 3 & 3 & 1 & 2 & & & 3 & 11 & 42 \\
\hline S 57 & 11 & 9 & 4 & 1 & & 6 & 2 & 1 & 2 & 1 & 7 & 44 \\
\hline S 58 & 8 & 4 & 6 & 2 & & 2 & & & & & 5 & 27 \\
\hline 計 & 55 & 33 & 18 & 13 & 13 & 10 & 9 & 6 & 5 & 5 & 52 & 219 \\
\hline$\%$ & 25.2 & 15.1 & 8.2 & 5.9 & 5.9 & 4.6 & 4.1 & 2.7 & 2.3 & 2.3 & 23.7 & 100 \\
\hline
\end{tabular}

では，年龄による著明な差は認められていな い。喉頭異物に抽いては， $0 \sim 10$ 歳の症例がな く, 逆に61歳以上の高齢者が約半数を占めてい た。食道・胃腸異物 (表 5 ) では，10歳以下と 51 歳以上の 2 つのグループにわかれ，1 例の気 管異物症例は 5 歳の女子であった。

次に異物の種類についてみると, 鼻腔内異物 （表 6 ）に関しては, 急病診療所の性格上, 簡 単に「球」と記載されたものが最も多く全体の 1/4を占め, ついで, プラスチック片, 豆類, 玩具となっているが，いずれも球形であるもの が多かった。咽頭異物（表 7 ）に関しては, 魚 骨が最も多く，約 $90 \%$ に達している。注かに針 金，10円玉，竹串，義歯などであった。喉頭異
表 5 食道・胃腸異物症例年齢分布

\begin{tabular}{c|cc|c|c}
\hline 年 齢 & 男 & 女 & 計 & 計 \\
\hline $0 \sim 5$ & 6 & 7 & 13 & 73.6 \\
$6 \sim 10$ & 2 & 1 & 3 & 15.8 \\
$11 \sim 50$ & 0 & 0 & 0 & 0 \\
$51 \sim 60$ & 0 & 1 & 1 & 5.3 \\
$61 \sim$ & 0 & 1 & 1 & 5.3 \\
\hline 計 & 8 & 11 & 19 & 100 \\
\hline
\end{tabular}

表 7 年度別咽喉頭異物別頻度

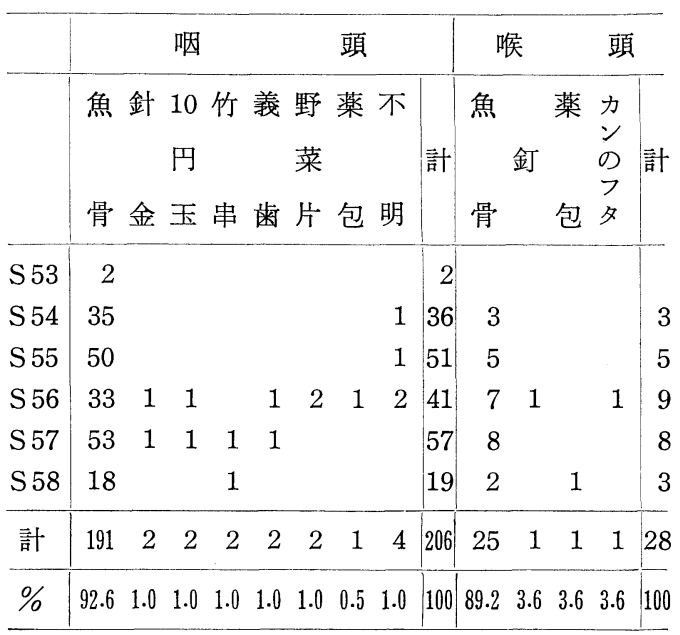

表 8 年度別食道・胃腸異物別頻度

\begin{tabular}{|c|c|c|c|c|c|c|c|c|c|c|c|}
\hline & $\begin{array}{c}1 \\
\text { 円 } \\
\text { 玉 }\end{array}$ & $\begin{array}{c}5 \\
\text { 円 } \\
\text { 玉 }\end{array}$ & $\begin{array}{l}10 \\
\text { 円 } \\
\text { 玉 }\end{array}$ & $\begin{array}{l}50 \\
\text { 円 } \\
\text { 玉 }\end{array}$ & $\begin{array}{l}100 \\
\text { 円 } \\
\text { 玉 }\end{array}$ & 薬 & $\begin{array}{l}1 \\
1 \\
2\end{array}$ & $\begin{array}{l}\text { パ } \\
\text { チ } \\
\text { ン } \\
\beth \\
\text { 玉 }\end{array}$ & ピ & 魚 & 計 \\
\hline S 53 & & & & & & & & & & & \\
\hline S 54 & & & & & 1 & & 1 & & & & 2 \\
\hline S 55 & & 2 & 1 & & & & & & & 1 & 4 \\
\hline S 56 & & & & & 2 & 1 & & & & & 3 \\
\hline S 57 & 1 & & 1 & 1 & & 1 & & 1 & 1 & & 6 \\
\hline S 58 & & & & 1 & 1 & & 1 & 1 & & & 4 \\
\hline 計 & 1 & 2 & 2 & 2 & 4 & 2 & 2 & 2 & 1 & 1 & 19 \\
\hline$\%$ & 5.3 & 10.5 & 10.5 & 10.5 & 21.1 & 10.51 & 10,510 & 0.5 & 5.3 & 5.3 & 100 \\
\hline
\end{tabular}

物（表 7) に関してもほぼ同様の傾向で, やは り魚骨が $90 \%$ 近くを占めていた。しかし，食道 ・胃腸異物（表 8 ）になると, やや異なった 傾向がみられた。すなわち，貨幣またはコイン といったものが19例中13例で最も多く, 活かに 
薬包，パチンコ玉，ピンなどがあり，魚骨は， わずか 1 例であった。

表 9 は, 食道・胃腸異物の存在部位を示す。 確認できたものは，19例中15例で，やはり食道 第一狭窄部が最も多く9例であった。胃内に達 っしているものが 3 例, 小腸にまで達っしてい るものも，50円玉，パチンコ玉の 2 例認められ た。

最後に受診までの時間を表10に示す。鼻腔内 異物之食道・胃腸異物, 咽頭異物之喉頭異物が 同じょうな傾向を示している。すなわち，前者 は10歳以下の患者が圧倒的に多いため，その活 動時間と診療所の午前 10 時より午後 5 時むでの 診療時間が関係し，後者では，食事の時間と診 療時間が関係した結果と思われる。

\section{III 結 語}

大阪市中央急病診療所に拈将る異物症の統計 的観察を抽こない，以下のような結果をえた。

1)耳内以外の異物症例は，全症例の約 $2 \%$ 占める。

2)鼻腔内異物, 咽頭異物が注湆同数で, 両者 で約 $90 \%$ を占める。

3)鼻腔内異物に関しては，5歳以下が圧倒的 に多く, 喉頭異物では逆に高齢者が多い。

4)具体的には，鼻腔内異物では球形物が，咽 喉頭異物では魚骨が多い。

5)受診までの時間をみると，大部分の患者は 6 時間内に受診している。

\section{文献}

1）松永喬 - 他：我教室10年間の異物症 統計，日耳 鼻, $70 ： 1373-1378,1967$.
表 9 食道・胃腸異物の種類と存在部位

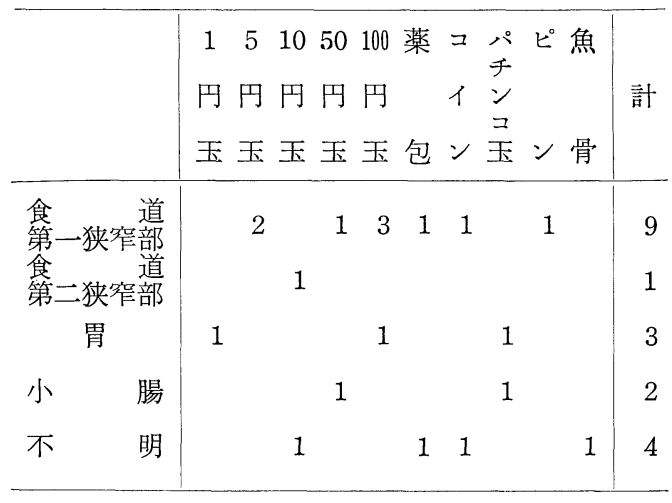

表 10 外来受診玉での時間

\begin{tabular}{|c|c|c|c|c|c|}
\hline 時間 & $0 \sim 6$ & $6 \sim 12$ & $12 \sim 24$ & $24 \sim 48$ & $48 \sim$ \\
\hline 鼻 & 162 & 4 & 36 & 3 & 14 \\
\hline$(\%)$ & $(74.0)$ & (1.8) & (16.4) & (1.4) & $(6.4)$ \\
\hline 咽 頭 & 99 & 13 & 82 & 5 & 7 \\
\hline$(\%)$ & $(45.1)$ & (6.3) & (39.8) & $(2.4)$ & $(3.4)$ \\
\hline 喉 頭 & 11 & 0 & 12 & 0 & 5 \\
\hline$(\%)$ & $(39.3)$ & & $(42.8)$ & & (17.9) \\
\hline $\begin{array}{c}\text { 気 管 } \\
(\%)\end{array}$ & 0 & 0 & 0 & 0 & $\begin{array}{r}1 \\
(100)\end{array}$ \\
\hline 食 道 & 5 & 0 & 3 & 0 & 1 \\
\hline$(\%)$ & $(78.9)$ & & $(15.8)$ & & $(5.3)$ \\
\hline
\end{tabular}

2）西浦勇夫 : 開業11年間異物症 例 の 統 計, 耳喉, $54: 471-477,1982$.

$\left(\begin{array}{r}\text { 別刷請求：干558 大阪市住吉区万代東3-1-56 } \\ \text { 大阪府立病院耳鼻咽喉科 } \\ \text { 長谷川 }\end{array}\right.$

（投稿受付 1984年 6 月11日） 